\title{
Learning Styles among TESL Undergraduates in University Putra Malaysia
}

\author{
Farah Nabillah Mior Yusup \\ University Putra Malaysia \\ E-mail: farahnabillah.mioryusup@gmail.com
}

Khaymalatha Balakrishnan

University Putra Malaysia

\author{
Doi:10.7575/aiac.alls.v.5n.4p.92 \\ URL: http://dx.doi.org/10.7575/aiac.alls.v.5n.4p.92
}

Received: 19/05/2014

Accepted: 01/07/2014

\begin{abstract}
Learning style is an individual's natural or habitual pattern of acquiring and processing information in learning situations. A core concept is that individuals differ in how they learn. This study focused on to look at a group of TESL undergraduates' preference in learning styles. The finding showed that the students have different kind learning styles in language learning. Most of them seem to have moderate preference on the active, sensing and global learning, mild preference on the reflective, intuitive, verbal and sequential learning and quite strong preferences for visual learning style. The finding of this study might help both educator and students in developing the pedagogical process and at the same time enhancing the effective learning and finally to improve themselves in the future.
\end{abstract}

Keywords: learning students, degree students, Malaysia

\section{Introduction}

Everyone has a mix of learning styles. Some people may find that they have a dominant style of learning, with far less use of the other styles. Others may find that they use different styles in different circumstances. There is actually no right mix. Nor are the styles fixed. Learners can develop ability in less dominant styles, as well as further develop styles that they already use well.

Learning styles and strategies have been variously described and defined. One such definition is 'styles' is the more general term, being “an individual's natural, habitual, and preferred way of absorbing, processing, and retaining new information and skills" (Kinsella, 1995, p. 171). These styles appear to be relatively stable and will be used by individuals regardless of the subject being studied or the skill being mastered by them in the field that they have chosen. Learning strategies are also the specific mental and communicative procedures that learners employ in order to learn and use language ( Chamot, 2005). Based on this, we can say that the right learning style will help the student in acquiring the language, while the teacher can find tune the lesson in order to be compatible with the student's learning style. The right use of strategy at the same time will enhance language learning success, states Green and Oxford (1995)

\section{Objectives}

This research is conducted in the aim of finding the learning styles of TESL students based on the Felder and Solomon learning styles. Solomon and Felder have outlined four different types of learning styles that has its own characteristics. Based on the questionnaire, this research aims to investigate on the learning styles that TESL students subscribe to.

\section{Research questions}

Below are the four research questions that this research looks at

1) Are TESL students more active or reflective learners?

2) Are TESL students more sensing or intuitive learners

3) Are TESL students more visual or verbal learners?

4) Are TESL students more sequential or global learners?

\section{Literature review}

Learning styles and strategies has always been a thing of interest and there have been many discussions on the styles and strategies that students use in their daily learning. As what has been defined by Brown (2000) learning styles can be considered as the manner in which people perceive and also process in the information in different learning situations, whereby here it simply means that each people may differ significantly with regard to their preferred learning styles. Students actually could learn in many ways, by seeing and hearing; reflecting and acting; reasoning logically and intuitively; memorizing and visualizing and drawing analogies and building mathematical models; steadily in fits and 
starts, (Richard M.Felder, Linda K.Silverman; Learning and Teaching Styles in Engineering Education). Learning in a structured educational setting may be thought of as a two step process, which is involving the reception and processing of information. In the reception step, external information (observable through the senses) and internal information (arising introspectively) become available to students. The students will select the material, process it and ignore the rest, (Richard M.Felder, Linda K.Silverman; Learning and Teaching Styles in Engineering Education).

According to Brown (2007), "Yet another dimension of learning style- one that is salient in formal classroom setting- is the preference that learners show toward visual, auditory and/or kinesthetic input." It is important to know what kind of learning style you have so that you could autonomies your learning, be aware of your comfortable styles, preferences, strengths and weaknesses and finally you will be able to take appropriate action especially in language learning. At the same time, Brown (2011) recommended that any courses should be well developed just to accommodate the different learning styles that the students have, so that it will be able to help the students to feel more comfortable in their language learning. This statement is also support by Nolting (2002) in his research,where he also claimed that students who are under their preferable learning styles could improve themselves well whether in or outside of the classroom. Language learning strategies are also can be classified into many different groups. Oxford (1990) considered that it can be divided into two groups, which are the direct and indirect strategies. The direct strategy includes memory, cognitive and compensation while the indirect strategy includes metacognitive, affective and social strategies.

This study is aimed at looking at TESL students preferences in learning style, as this would lead to see what sort of teaching methods these students would employ in teaching English as a second language

\section{Methodology}

The sample of the study was the 35 TESL undergraduates' students of first and second year of University Putra Malaysia. All of them are enrolled in Bachelor of Education (TESL) in University Putra Malaysia. They were randomly selected and were given the Index of Learning Strategies (ILS) questionnaires by Solomon and Felder. The Index of Learning Styles (ILS) has 44 items and it can be used to identify what kind of learning styles amongst the TESL undergraduates in UPM.

To measure the preference learning styles amongst the TESL Undergraduates in UPM, once the data was collected, the data was transferred to a another scoring sheet. All the data collected were then computed into form of group statistic using SPSS version 20. The finding are compared, analysed and discussed into mean of the overall results. The data are being converted into eight tables that display the result of the students' preference of learning styles. And from the finding, we could determine whether the learning styles are mildly, moderately or strongly preferred by the students in assisting their learning.

\section{Results and discussion}

The ILS questionnaire finding has been analyzed and compiled using the ILS scale. The mean scores of the results were plotted as shown in the diagram below.

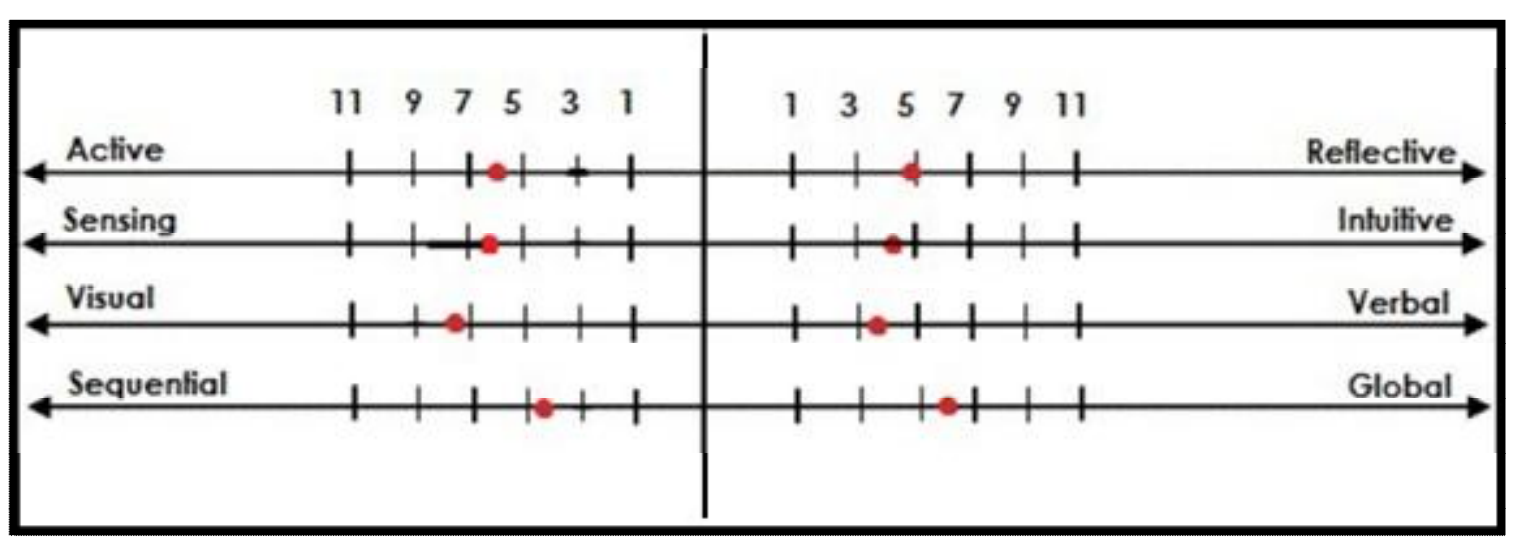

Figure 1. ILS scale for undergrad TESL students:

As what can be seen in the diagram above, after plotting the mean scores, we can see that mean score 6.06 was obtained on the left hand side for active learning and 4.94 mean score on the right hand side for the reflective learning. These results mean that the students have moderate preference for active learning and mild preference for the reflective learning.

For the option sensing and intuitive learning, the mean score that has been obtained were 6.31 on the left hand side which is for sensing and 4.69 mean score for the right hand side which is for the intuitive learning. This indicates that the students also have moderate preference for sensing learning and mild preference for the intuitive learning.

Moving on to the third category which were the visual and verbal learning styles, the mean score obtained from the above diagram were 7.86 score for visual learning style and 3.14 score for verbal learning style. These results simply 
mean that the students have fairly strong preference towards visual learning style but a little bit mild preference towards verbal learning style.

And the last category of learning styles, which were the sequential and global the mean score obtained were 4.91 score on the left hand side, which is for the sequential learning and 6.11 score on the right hand side which is for the global learning style. It is clear to us that the students seem to have mild preference for sequential learning but, on the other hand, they have moderate preference for the global learning style.

Mean scores: For a clear view of the students' scores of their preferable learning styles, the mean for each different category were calculated. The table below shows the results of learning styles preference for the Tesl Undergraduates Students.

Table 1. Mean values for students for B. Ed (TESL)

\begin{tabular}{lccc}
\hline & $\mathrm{N}$ & Mean & Std. Deviation \\
\hline ACTIVE & 35 & 6.06 & 2.363 \\
REFLECTIVE & 35 & 4.94 & 2.363 \\
SENSING & 35 & 6.31 & 2.233 \\
INTUITIVE & 35 & 4.69 & 2.233 \\
VISUAL & 35 & 7.86 & 2.545 \\
VERBAL & 35 & 3.14 & 2.545 \\
SEQUENTIAL & 35 & 4.91 & 2.133 \\
GLOBAL & 35 & 6.11 & 2.193 \\
Valid N (listwise) & 35 & & \\
\hline
\end{tabular}

This paper shows the analysis of learning style preference of Bachelor of Education TESL in University Putra Malaysia. According to the results obtained, the students have different kind learning styles in language learning. Most of them seem to have moderate preference on the active, sensing and global learning, mild preference on the reflective, intuitive, verbal and sequential learning and quite strong preferences for visual learning style.

For the first category, the students seem to have moderate preference on the active learning compare to mild preference for the reflective learning style because maybe they feel that it is easier to understand something by actively doing it. For example, doing group activities is seen as a good activity for them whereby the have opportunity to discuss and explain the topics to each other. By doing this, it will be easier for the students the topic and finally improving the retention towards the topics.According to Solomon and Felder, these are the characteristics of Active/ Reflective learners where the active learners tend to retain and understand information best by doing something active with it-discussing or applying it or explaining it to others. Reflective learners also prefer to think about it quietly first."Let's try it out and see how it works" is an active learner's phrase; "Let's think it through first" is the reflective learner's response. Active learners tend to like group work more than reflective learners, who prefer working alone and merely sitting through lectures without getting to do anything physical but take notes is hard for both learning types, especially for active learners.

For the second category, the students tend to have moderate preference for sensing learning compare to mild preference for intuitive learning. This might due to the fact that the students like the meaningful learning which is related to the real world situation. When it is related to real word it will be easy for them to interpret the lesson especially when it come to language learning where it definitely cannot be separated from real life situation. Solomon and Felder stated that sensing learners tend to like learning facts; intuitive learners often prefer discovering possibilities and relationships. They tend to like learning facts; intuitive learners often prefer discovering possibilities and relationships. Sensing learners also tend to like learning facts while the intuitive learners often prefer discovering possibilities and relationships. Sensors tend to be more practical and careful than intuitors; on the other hand, intuitors tend to work faster and to be more innovative than sensors. Sensors don't like courses that have no apparent connection to the real world while intuitors don't like "plug-and-chug" courses that involve a lot of memorization and routine calculations.

Moving on to the third category, the students have fairly strong preference towards visual learning compared to mild preference to verbal learning. Visual learners tent to remember what they see like pictures, diagrams, flow-chart, figures and so on. In understanding certain concept, it will definitely require the students to have this visual learning style. By using concept mapping, it will be easy for the students to understand the lesson or theory that they have learnt clearly. Solomon and Felder claimed that Visual learners remember best what they see--pictures, diagrams, flow charts, time lines, films, and demonstrations. Verbal learners get more out of words--written and spoken explanations. Everyone learns more when information is presented both visually and verbally.

And last but not least, for the forth category, the students have moderate preference towards global learning and fairly mild preference towards the sequential learning. This might due the fact that they would prefer to organize information more holistically to understand it better. They tend to relate the subject to things that they have already known just to 
get the bigger picture of it. For example in reading, they will just skimming through the text to get the overview first before they could look at other specific information from the text. Solomon and Felder also had characteristics for these types of learners where the sequential learners tend to gain understanding in linear steps, with each step following logically from the previous one. Global learners on the other hand, tend to learn in large jumps, absorbing material almost randomly without seeing connections, and then suddenly "getting it."Sequential learners also tend to follow logical stepwise paths in finding solutions; while the global learners may be able to solve complex problems quickly or put things together in novel ways once they have grasped the big picture, but they may have difficulty explaining how they did it

\section{Conclusion}

In conclusion, knowing and being aware of the students preferable learning styles can be regarded as important whereby it can improve the adaptability in teaching and learning process. It will also help in enhancing the pedagogical process and at the same time supporting the effective learning and finally the students will also be able to improve themselves in the future.

Students do not necessarily have to use all of the learning styles mentioned above, but rather to choose which one is better and feasible to be used in the classroom especially in helping them to understand the lesson better. At the same, lecturer could also know what kind of materials should be used in the classroom to cater the students' needs and end of the day; these actually will bring benefits to both parties as well. By doing this, both lecturer and students could possibly having an effective teaching and learning process together.

\section{References}

Branch, L. (2012). Visual, Auditory, Kinesthetic learning Styles and Their Impacts on English Language Teaching. Journal of Studies in Education Vol. 2, No.1 Retrieved $4^{\text {th }}$ April 2014 from http://www.macrothink.org/journal/index.php/jse/article/download/1007/1066

Brown, H. (2007). Principles of Language Learning and Teaching ( $5^{\text {th }}$ Ed.). New York: Pearson Education.

Felder, R.M., and Solomon, B.A. (n.d.).Index of Learning Styles. Retrieved from http://www4.ncsu.edu/unity/lockers/users/f/felder/public/ILSpage.html

Felder, R.M., and Solomon, B.A. (n.d.). Learning Styles and Strategies. Retrieved from http://www4.ncsu.edu/unity/lockers/users/f/felder/public/ILSdir/styles.htm

Journal of Education and Vocational Research (2012). Analysis of Felder and Solomon Index of Learning Styles of

Students from Management and Engineering at University of Mauritius. Retrieved from

http://www.academia.edu/2542335/Analysis_of_Felder-

Solomon_Index_of_Learning_Styles_of_Students_from_Management_and_Engineering_at_the_University_of_Mauriti us

Westbrook Amy, F. (2011). The Effects of Differentiating Instruction by Learning Stles On Problem Solving in $\begin{array}{llllll}\text { Cooperative } & \text { Groups. } & \text { Retrived } & 20^{\text {th }} & \text { April } & 2014\end{array}$ http://eric.ed.gov/?q=journal+related+to+learning + styles\&ft=on\&id=ED529983 